\title{
A Study on the Difficulties and Countermeasures of Sino-foreign Cooperation in Running Schools in Colleges and Universities
}

\author{
Rui Ge \\ Office of International Cooperation and Exchange, Huaiyin Institue of Technology, Huai'an 223001, Jiangsu, China \\ DOI: $10.32629 /$ jher.v2i6.578
}

\begin{abstract}
The dilemma of Sino-foreign cooperation in running schools in colleges and universities is reflected in the disharmony between the objectives of cooperative running schools, curriculum arrangement, different levels of students' competence and curriculum difficulty. colleges need to strengthen the system construction, supervise Sino-foreign cooperation in running schools, formulate scientific and reasonable teaching plans and management methods, and strengthen the construction of teaching team of introduced courses. Scientifically and reasonably formulate enrollment standards, and strengthen the construction of the Management Committee of Chinese foreign cooperation in running schools.

Keywords: colleges and universities, Sino-foreign cooperation, running schools, dilemma, countermeasure
\end{abstract}

\section{Introduction}

Sino-foreign cooperation in running schools not only facilitates domestic educational institutions to observe and learn foreign advanced education and teaching practices, but also promotes the exchange between domestic and foreign teachers, makes domestic teachers understand the latest foreign research trends in relevant fields faster, improves the scientific research level of domestic teachers, and plays a positive role in improving the domestic education level. Identify many problems faced by colleges and universities in the process of Sino-foreign cooperation in running schools, understand their root causes, and put forward strategies to improve the effect of Sino-foreign cooperation in running schools.

\section{The difficulties of Sino-foreign cooperation in running schools in colleges}

\subsection{The goal of cooperative school running is divorced from the realistic foundation}

When preparing for the establishment of Sino-foreign cooperative school running projects (or institutions), colleges usually expect too much from the foreign side and determine higher and more ideal cooperative school running objectives. However, due to the limited human, material and financial resources and low international popularity, ordinary colleges can only cooperate with "ordinary" foreign colleges or foreign colleges with lower levels, so it is difficult to achieve the ideal school running goal. When the established goal of cooperative school running becomes far from timely, the teaching and project management are naturally lax, and the teaching (training) and project management become mechanical repetitive actions, from which we cannot draw nutrition.

\subsection{Unreasonable course arrangement}

The curriculum connection of Sino-foreign cooperative school running projects (or institutions) is not close enough. There are more courses in the lower grades and fewer courses in the upper grades, so there is a phenomenon of "tight in the front and loose in the rear". Since the learning courses are mainly concentrated in the spring and autumn semesters, it is difficult for foreign teachers to teach in China for a long time in the spring and autumn semesters. Therefore, the introduced foreign courses are either set up in the short semesters in the summer, or short-term concentrated teaching in the spring and autumn semesters, resulting in excessive concentration of courses at the lower levels of the University, and the communication obstacles between foreign teachers and Chinese students, The teaching effect is poor.

\subsection{Students' competence and course difficulty are not coordinated}

Under the influence of social prejudice, awareness, tuition pressure and other factors, ordinary colleges and universities have to reduce the admission batch and score to complete the enrollment plan of Sino-foreign cooperative education. Although the enrollment scores of students in Sino-foreign cooperative school running projects (or institutions) are usually low, the learning pressure is generally greater than that of non cooperative school running majors. In order to adapt to foreign language teaching, Sino-foreign cooperative education should not only increase the teaching hours of foreign language courses, but also collect the advantages and characteristic courses of both parties. Therefore, the actual number and difficulty 
of core courses can only be higher than that of similar non cooperative education majors. The contradiction between weak student foundation and high learning intensity makes many students in cooperative school running projects (or institutions) unable to keep up with the pace of teaching.

\subsection{Students' foreign language level is difficult to adapt to foreign language teaching}

Foreign language application ability should have been the feature and advantage of cooperative school running, but students' weak foreign language foundation is a common phenomenon. Because of the pressure of enrollment, the foreign language foundation of Chinese foreign cooperative students in Colleges and universities is low, so it is difficult to form effective interaction with foreign teachers. When colleges and universities cooperate with non English speaking countries, students' foreign language ability is insufficient. When running a school in cooperation with small language countries, a second foreign language course is opened with a large number of class hours after students enter the school, so as to adapt to foreign teaching, increase students' learning difficulty and reduce teaching effect.

\subsection{Poor communication between Chinese and foreign teachers}

The management power of colleges and universities is usually concentrated, the management department has more directives, and the independent authority of colleges and departments (majors) is less. When foreign teachers come to China to teach classes, they are mainly communicated by the heads of the school's foreign affairs department and teaching units, and there is less communication with Chinese teachers, especially those who do not teach in cooperative school running projects. Due to teaching pressure, foreign teachers do not have the energy to discuss teaching methods, ideas and feelings with Chinese teachers. Therefore, the demonstration effect of foreign advanced teaching ideas and teaching methods on Chinese teachers is limited. In addition, because foreign teachers do not understand Chinese teachers' teaching forms, educational ideas and students' learning habits, they can not reasonably adjust teaching methods, let alone combine advanced teaching methods with Chinese actual teaching, so it is difficult to achieve the purpose of cooperative school running.

\section{The countermeasures of Sino-foreign cooperation in running schools in Colleges}

\subsection{Improve the examination, approval and supervision system for the qualification of Chinese foreign cooperation in running schools}

The Ministry of Education shall introduce an authoritative third-party institution to conduct objective and comprehensive evaluation on the teaching and scientific research of foreign school running institutions and their cooperative majors to be cooperated, and take this as the basis for prudent and strict examination and approval. In addition, the foreign party should also be required to provide the opening plan, which should be regarded as an important part of the cooperative school running contract, so as to ensure that the teaching plan when applying for cooperative school running is consistent with the reality.

\subsection{Strengthen the direct supervision over the process of cooperative school running and ensure the investment in school running}

We should change the rough mode of annual supervision in the form of annual report of cooperative school running, supplemented by review every few years. In particular, it is necessary to formulate detailed rules for the management of foreign courses, such as foreign teaching standards and student satisfaction, conduct random sampling from the three levels of schools, majors and students, and establish an effective supervision mechanism, so as to prevent Chinese school running units from concealing foreign problems in cooperative school running from the examination authority in order to continue cooperative school running.

\subsection{Arrange the teaching content scientifically and set the course difficulty reasonably}

Some key theories will be repeated in different courses. These contents should not be repeated in general. They should be carefully taught in appropriate courses, while they should be paved and reviewed in other courses. In addition, less class hours are used to teach foreign courses in advance or supplement them, so as to ensure the connection of courses while evenly distributing class hours.

\subsection{Strengthening the construction of auxiliary teaching team of introduced courses}

Organize Chinese teachers to form a teaching team and connect with foreign courses. Make planned preparation for the newly introduced foreign courses through observation and teaching. Chinese courses shall be matched and connected with foreign courses, and the Chinese Cooperative specialty shall carry out general management. For the introduced foreign courses, it is necessary to specify the Chinese docking teaching team. The teaching team is in the charge of a specially 
assigned person to pre teach the contents or basic knowledge of the introduced courses, so as to help students digest and absorb the contents of the introduced courses smoothly and effectively.

\subsection{Scientifically and reasonably formulate and implement enrollment standards}

In combination with the foreign teaching language and professional characteristics in the process of Sino-foreign cooperation in running schools, formulate scientific and reasonable enrollment standards and put forward clear admission requirements for foreign language ability, so as to ensure that students can adapt to the foreign teaching language. Formulate enrollment standards according to the teaching plan of cooperative education, especially the teaching language of foreign courses. The enrollment standards (or enrollment requirements) shall be formulated by the Teaching Department of the cooperative school. After being submitted to the Cooperative School Management Committee for approval, the enrollment department shall recruit students according to the requirements.

\subsection{Strengthen the construction of the Administrative Committee for Chinese foreign cooperation in running schools.}

Formulate and publicize the time plan of the regular meeting, earnestly implement the plan of the regular meeting, and regularly feedback and submit the actual problems existing in the teaching and management of the cooperative school; Promote the coordination, communication and cooperation between the multi-level functional departments of the two universities, and timely and effectively solve the problems in cooperative school running. Giving full play to the function of cooperative school running management committee is particularly important for local colleges and universities with serious "administration".

\section{Conclusion}

This paper analyzes the current difficulties in cooperative running of colleges and universities from six aspects: the separation between reality and school running objectives, unreasonable curriculum design, great difficulty in curriculum design, low students' foreign language level and poor communication between Chinese and foreign teachers and students. On this basis, it puts forward to improve the qualification approval and supervision system of cooperative running of colleges and universities, ensure school running investment, scientifically arrange teaching contents, reasonably set curriculum difficulty Strengthen the construction of teaching team, scientifically formulate enrollment standards and establish a cooperative school running management committee, so as to improve the quality of Sino-foreign cooperative school running in Colleges.

\section{References}

[1] Chi Haitao. How to achieve breakthrough development in Sino-foreign cooperation in running schools in Colleges and universities[J]. China Adult Education, 2018, (9): 72-74.

[2] Li Haihui, Gao Xuemei. Current situation, problems and Countermeasures of Sino-foreign cooperation in running schools at undergraduate level[J]. Heilongjiang Higher Education Research, 2018, (3): 54-57.

[3] Wang Mingyi. How to scientifically operate academic power and administrative power in local universities[J]. China higher education research, 2012, (12): 69-73. 